УДК 66 2.998:504.5

ОЦЕНКА ВОЗДЕЙСТВИЯ НА ОКРУЖАЮЩУЮ СРЕДУ

РАЗЛИЧНЫХ ТЕПЛОИЗОЛЯЦИОННЫХ МАТЕРИАЛОВ

\title{
ENVIRONMENTAL IMPACT ASSESSMENT OF VARIOUS THERMAL INSULATION MATERIALS
}

\author{
А.М. Газизов, А.А. Заиров, Р.Р. Янгирова, М.Р. Тимеров
}

Уфимский государственный нефтяной технический университет,

$$
\text { г. Уфа, Российская Федерация }
$$

Уральский государственный лесотехнический университет,

г. Екатеринбург, Российская Федерация

\section{Asgat M. Gazizov, Aydar A. Zairov, Regina R. Yangirova, Marsel R.Timerov}

Ufa State Petroleum Technological University, Ufa, Russian Federation Ural State Forest Engineering University,

Ekaterinburg, Russian Federation

$$
\text { e-mail: ashatgaz@mail.ru }
$$

Аннотация. В статье приведены некоторые характеристики крупнейших месторождений высококачественного базальта России как сырьевых, баз предприятий теплоизоляционных материалов (ТИМ), охарактеризованы виды ТИМ, описано изготовление ТИМ из отходов производства, а также виды воздействия на окружающую среду при производстве ТИМ. Кроме того, рассмотрены некоторые методы снижения воздействия на окружающую среду при производстве ТИМ и определены задачи дальнейших исследований.

Показатель первичных энергозатрат служит единым параметром для оценки воздействий на окружающую среду, причиной которых являются 
поставки энергии на производство. Для оценки приводится только та доля энергии, которая получена из невозобновляемых источников. Кроме энергозатрат, в качестве важных критериев оценки воздействий на окружающую среду среди всех рассмотренных, были выбраны потенциалы создания парникового эффекта, закисления, разрушения озонового слоя, образования фотохимического смога и переудобрение почв.

Рассчитанные эквивалентные показатели первичных энергозатрат, потенциала создания парникового эффекта и потенциала закисления приводятся к соответствующей толщине слоя теплоизоляционного материала, который позволяет достичь определенного сопротивления теплопередаче.

В настоящей статье приведен анализ распространенных в отечественной практике неорганических волокнистых теплоизоляционных материалов от начала производства до утилизации.

Из проведенного анализа воздействий на окружающую среду по жизненному циклу волокнистых теплоизоляционных материалов является то, что система рассмотренных критериев по стандарту ИСО 14040 не позволяет подробно учитывать локальные воздействия на экосистемы вблизи производств.

В связи с этим вблизи расположения производства следует учитывать отдельные локальные критерии, позволяющие более объективно оценивать экологическую безопасность предприятий-производителей волокнистых теплоизоляционных материалов.

Для более точной оценки безопасности волокнистых теплоизоляционных материалов необходима постановка многофакторного эксперимента со входными параметрами: X1 - марка теплоизоляционного материала (ТИМ); Х2 - размеры ТИМ; Х3 - состав ТИМ и выходными - У1 - пыль; У2 - содержание химических примесей.

Abstract. The article presents some characteristics of the largest deposits of high-quality basalt in Russia, as raw material bases for enterprises of thermal 
insulation materials (TIM), characterizes the types of TIM, describes the manufacture of TIM from production wastes, as well as the types of environmental impact during the production of TIM. In addition, some methods of reducing the environmental impact of TIM and the tasks of further research are considered.

The indicator of primary energy consumption serves as a single parameter for assessing the environmental impacts caused by the supply of energy to production. For the assessment, only the share of energy that is obtained from non-renewable sources is given. In addition to energy costs, among all those considered, the potential for creating a greenhouse effect, acidification potential, ozone layer destruction potential, soil over-fertilization, and the potential for the formation of photochemical smog were chosen as important criteria for assessing the impact on the environment.

The calculated equivalent indicators of primary energy consumption, potential for greenhouse effect and acidification potential are reduced to the corresponding thickness of the layer of thermal insulation material, which makes it possible to achieve a certain resistance to heat transfer.

This article provides some analysis of inorganic fibrous thermal insulation materials common in domestic practice, from the beginning of production to disposal.

From the analysis of the environmental impacts on the life cycle of fibrous thermal insulation materials, it is clear that the system of the considered criteria according to the ISO 14040 standard does not allow for a detailed consideration of local impacts on ecosystems near production facilities.

In this regard, near the location of the production, individual local criteria should be taken into account, which make it possible to more objectively assess the environmental safety of enterprises producing fibrous thermal insulation materials

For a more accurate assessment of the safety of fibrous heat-insulating materials, it is necessary to set up a multifactor experiment with input parameters: 
X1 - grade of heat-insulating material (TIM); X2 - TIM dimensions; X3 - the composition of TIM and output parameters: U1 - dust; U2 - chemical impurities content.

Ключевые слова: теплоизоляционные материалы; сырье; минеральная вата; окружающая среда; отходы производства; состав; оценка

Key words: thermal insulation materials; raw materials; mineral wool; environment; industrial waste; composition; assessment

До сих пор в нашей стране под утилизацией строительных материалов понимается только один процесс - вывоз на полигон. Вопросы экологии в этой области волнуют в основном производителей теплоизоляционных материалов (ТИМ).

Оценка воздействия материалов и других типов продукции на окружающую среду, в соответствии с требованиями Федерального закона №184-Ф3 от 27.12.2002 «О техническом регулировании» (в редакции 29 ноября 2019 г.) и со стандартами ИСО серии 14040, производится по всему жизненному циклу от начала производства до утилизации.

Первым этапом жизненного цикла является добыча и подготовка сырьевых компонентов. Российская Федерация обладает хорошей базой для производства волокон из каменного расплава как в европейской части, так и на Урале, в Сибири и на Дальнем Востоке. Например, в европейской части России могут использоваться местные глины, известняки, доломиты и базальты Карелии. При этом важно взаимное месторасположение основных крупнейших месторождений базальта и производств минераловатных изделий по стране. В частности, Дальний Восток и Сибирь, где потребление теплоизоляции должно расти в связи с климатическими условиями, по данным консалтингового агентства IndexBox, в значительной мере ориентированы на потребление импортной продукции [1]. В тоже время, например, Судунтуйское месторождение в Читинской области обладает 
запасами высококачественного базальтового сырья [2]. Базальты этого месторождения залегают на небольшой глубине, что позволяет организовать их добычу открытым способом. Основными минералами базальта Судунтуйского месторождения являются плагиоклазы и оливины.

Порода Судунтуйского месторождения, имея химический состав, представленный в таблице 1, относится по этому показателю к высшей категории качества, что дает возможность применения в технологическом процессе однокомпонентной шихты без добавления оксидов щелочноземельных металлов [2].

Таблица 1. Сравнительный химический состав базальтовой породы сырьевых месторождений

\begin{tabular}{|l|l|l|l|l|l|l|l|l|l|l|l|l|l|}
\hline $\begin{array}{c}\text { Наименование } \\
\text { месторождения }\end{array}$ & \multicolumn{10}{|c|}{ Химический состав базальта, \% по массе } \\
\hline $\begin{array}{l}\text { Судунтуйское } \\
\text { (Читинская } \\
\text { область) }\end{array}$ & 48,6 & 5,8 & 16,9 & 4,6 & 0,2 & 2,4 & 6,8 & 2,1 & 4,7 & 3,3 & 0,9 & 0,1 & 2,6 \\
\hline
\end{tabular}

По Дальневосточному региону количество месторождений сырья для теплоизоляционных материалов (в частности, базальтовых пород), по данным [3], составляет не менее 5. Месторождения на данный момент находятся на разных стадиях освоения: разработка, резерв, консервация. Несмотря на снижение добычи в связи с кризисом горной промышленности края, в целом специалисты констатируют потенциал развития известных месторождений и разведки новых минеральных площадей.

Подготовка сырья (добыча, измельчение, смешивание компонентов шихты) требуют затрат энергии, эти затраты для различных месторождений сырья и технологий показаны в таблице 2. 
Таблица 2. Энергозатраты на подготовку сырья и температурный интервал плавления сырьевых компонентов для производства изделий из каменной ваты

\begin{tabular}{|c|c|c|}
\hline $\begin{array}{c}\text { Наименование месторождения и } \\
\text { порода }\end{array}$ & $\begin{array}{c}\text { Энергозатраты } \\
\text { на подготовку сырья, } \\
\text { кВт/м }{ }^{3}\end{array}$ & $\begin{array}{c}\text { Температурный интервал } \\
\text { плавления сырьевых } \\
\text { компонентов, }{ }^{\circ} \mathrm{C}\end{array}$ \\
\hline $\begin{array}{l}\text { Судунтуйское (Читинская область) - } \\
\text { базальт }\end{array}$ & 40,0 & $1150-1450$ \\
\hline $\begin{array}{l}\text { Хавчозерское (Республика Карелия) - } \\
\text { пироксеновый порфирит }\end{array}$ & 42,3 & $1175-1300$ \\
\hline $\begin{array}{l}\text { Кусинск-Копанская группа интрузий } \\
\text { (Южный Урал) - анортозиты }\end{array}$ & 54,4 & $1200-1400$ \\
\hline
\end{tabular}

Меньшие энергозатраты при использовании базальтов Судунтуйского месторождения связаны с их открытой добычей, а также с тем, что они практически не требуют подшихтовки известняком благодаря подходящему модулю кислотности. Кроме того, при дальнейшей технологической обработке сырье данного месторождения также имеет преимущества за счет более низких значений в температурном интервале плавления.

Немного более низкий интервал температур плавления пироксенового порфирита (Хавчозерского месторождения, Карелия) по сравнению с базальтами определяется присутствием в его составе актинолита (30-35 \%) и хлорита (20-25\%), температура плавления которых ниже температуры плавления плагиоклаза, пироксенов (авгита и диопсида), оливина, магнетита, формирующих состав базальта Берестовецкого месторождения (Украина).

Процесс производства волокнистых теплоизоляционных материалов предусматривает следующие основные этапы: получение расплава; вытягивание волокна из расплава; добавление связующих веществ и компонентов, снижающих пыление и придающих водоотталкивающие свойства; укладка на конвейер и транспортировка в камеру отверждения связующего; нанесение каширующих покрытий (при необходимости) или прошивка матов; придание формы изделиям при помощи их распиловки. Возникающие в ходе производственного процесса отходящие газы проходят через механические фильтры и циклоны, а затем, по возможности, 
дожигаются. Производимое при этом тепло через теплообменник может использоваться для предварительного разогрева печи. Пыль, образующаяся в процессе резки волокнистого холста на готовые изделия, должна собираться и вновь использоваться в качестве сырья для расплава. Используемая в производственном процессе вода после очистки применяется вновь благодаря оборотной системе водоснабжения [4].

В производстве стекловолокна и изделий из него применяются ванные печи на газообразном и жидком топливе, а в производстве тонкого и супертонкого базальтового волокна - электропечи с графитовыми или молибденовыми электродами или индукционные печи.

В России волокно получают при помощи центробежных дутьевых установок, а на ведущих европейских предприятиях - на многовалковых центрифугах. При этом снижаются потери при использовании пара, расход которого 1,5-2 т/ч на 1 центрифугу, что ниже расхода при использовании центробежной дутьевой установки в 3 раза. При использовании многовалковых центрифуг повышается качество волокна диаметром 4-5 мкм, в частности, его прочность и упругость. Таким образом, показатели энергоемкости производства волокнистых теплоизоляционных материалов (таблица 3) имеют ярко выраженную технологическую специфику.

Таблица 3. Производительность и средние энергозатраты на производство различных плавильных агрегатов

\begin{tabular}{|c|c|c|}
\hline $\begin{array}{c}\text { Наименование плавильного } \\
\text { агрегата }\end{array}$ & $\begin{array}{c}\text { Производительность } \\
\text { по расплаву, т/ч }\end{array}$ & $\begin{array}{c}\text { Средние энергозатраты } \\
\text { на производство, кВт·ч/кг } \\
\text { полученного изделия }\end{array}$ \\
\hline Коксовые вагранки & $2-2,5$ & $4,0-6,0$ \\
\hline $\begin{array}{l}\text { Ванные печи минераловатных } \\
\text { производств }\end{array}$ & $1,6-2,5$ & $3,7-5,0$ \\
\hline Электропечи & 5 & $3,2-4,2$ \\
\hline $\begin{array}{l}\text { Ванные печи производств } \\
\text { стекловолокна }\end{array}$ & $0,8-1,5$ & $3,5-4,0$ \\
\hline $\begin{array}{l}\text { Печи базальтового } \\
\text { производства }\end{array}$ & 0,2 & $3,7-5,5$ \\
\hline Плазменнодуговая печь & 0,05 & $2-3$ \\
\hline
\end{tabular}


В таблице 4 приведены расчетные данные по первичным энергозатратам на производство тех или иных теплоизоляционных изделий из волокна в зависимости от технологии (в частности, способа и оборудования для плавления шихты).

Таблица 4. Показатели первичных энергозатрат при производстве волокнистых теплоизоляционных материалов

\begin{tabular}{|c|c|c|}
\hline $\begin{array}{l}\text { Наименование волокнистых } \\
\text { теплоизоляционных изделий }\end{array}$ & $\begin{array}{c}\text { Первичные } \\
\text { энергозатраты } \\
\text { (невозобновляемой } \\
\text { энергии), МДж/кг } \\
\text { готовой продукции }\end{array}$ & $\begin{array}{c}\text { Первичные } \\
\text { энергозатраты } \\
\text { (возобновляемой } \\
\text { энергии), МДж/кг } \\
\text { готовой продукции }\end{array}$ \\
\hline $\begin{array}{l}\text { Плиты из каменной ваты, изготовленные } \\
\text { по технологии с использованием ванной } \\
\text { печи, без покрытий средней плотностью } \\
\text { от } 25 \text { до } 180 \text { кг } / \text { м }^{3}\end{array}$ & 18,80 & 0,1 \\
\hline $\begin{array}{l}\text { Плиты из стекловаты, изготовленные по } \\
\text { технологии с использованием ванной } \\
\text { печи, без покрытий средней плотностью } \\
20-100 \text { кг/м }\end{array}$ & 35,47 & 0,2 \\
\hline $\begin{array}{l}\text { Плиты из каменной ваты, изготовленные } \\
\text { по технологии с использованием вагранки, } \\
\text { без покрытий средней плотностью } \\
\text { от } 25 \text { до } 180 \text { кг } \mathrm{M}^{3}\end{array}$ & 25,4 & 2,5 \\
\hline $\begin{array}{l}\text { Плиты из стекловаты, изготовленные по } \\
\text { технологии с использованием вагранки, } \\
\text { без покрытий средней плотностью } \\
20-100 \text { кг/м } \\
\end{array}$ & 38,7 & 2,7 \\
\hline $\begin{array}{l}\text { Плиты из каменной ваты, изготовленные } \\
\text { по технологии с использованием } \\
\text { электродуговой плазменной печи, без } \\
\text { покрытий средней плотностью от } 25 \text { до } \\
180 \text { кг/м }\end{array}$ & 12,9 & 0,1 \\
\hline
\end{tabular}

Кроме энергозатрат, в качестве важных критериев оценки воздействий на окружающую среду среди всех рассмотренных были выбраны

- потенциал создания парникового эффекта,

- потенциал закисления,

- потенциал разрушения озонового слоя,

- переудобрение почв,

- потенциал образования фотохимического смога.

Для корректного проведения оценки должны сопоставляться теплоизоляционные материалы одинакового функционального назначения. 
В связи с этим для каждого оцениваемого материала определяют толщину слоя, соответствующую стандартному показателю сопротивления теплопередаче.

Потенциал создания парникового эффекта описывает все возникающие в процессе производства эмиссии газов, приводящие к повышению температуры атмосферы Земли (так называемые парниковые газы). Данные приводятся в пересчете на $\mathrm{CO}_{2}$-эквивалент в килограммах. Таким образом, влияние различных газов на потенциальное глобальное потепление приводится к возможному влиянию, вызванному пребыванием в атмосфере на протяжении 100 лет 1 кг диоксида углерода. В соответствующем размере учитывается также эффект связывания $\mathrm{CO}_{2}$ в производственном процессе.

Потенциал закисления описывает сумму всех возникающих в процессе производства газовых эмиссий, которые приводят к закислению водоемов и почв через образование кислот в сочетании с водой (например в виде кислотных осадков). Данные приводятся обычно в килограммах $\mathrm{SO}_{2}$-эквивалента, т.е. в пересчете на образование максимально возможного количества кислотообразующих соединений при растворении в воде килограмма диоксида серы.

Разрушение озонового слоя характеризуется приведенным значением выделяющихся по всему жизненному циклу хлорфторуглеводородов.

Потенциал переудобрения почв рассчитывается, в свою очередь, в таком эквиваленте, как количество фосфатов на 1 кг волокнистых готовых изделий, а потенциал образования фотохимического смога - в этиленэквиваленте.

В таблице 5 приведены данные расчетов по указанным критериям для различных производств волокнистых теплоизоляционных материалов. 
Таблица 5. Анализ воздействий на окружающую среду при производстве волокнистых теплоизоляционных изделий в пересчете на эквивалентные единицы

\begin{tabular}{|c|c|c|c|c|c|}
\hline $\begin{array}{c}\text { Наименование } \\
\text { материала }\end{array}$ & $\begin{array}{c}\text { Потенциал } \\
\text { создания } \\
\text { парникового } \\
\text { эффекта, } \\
\text { кг } \mathrm{CO}_{2} \text {-экв./м² }\end{array}$ & $\begin{array}{c}\text { Потенциал } \\
\text { окисления, } \\
\mathrm{SO}_{2-} \\
\text { экв./M } \mathrm{M}^{2}\end{array}$ & $\begin{array}{c}\text { Потенциал } \\
\text { разруше- } \\
\text { ния озона, } \\
\text { кг СFС- } \\
\text { экв. }\end{array}$ & $\begin{array}{l}\text { Потенциал } \\
\text { пере- } \\
\text { удобрения, } \\
\text { кг } \mathrm{PO}_{2} \text {-экв. }\end{array}$ & $\begin{array}{c}\text { Потенциал } \\
\text { образования } \\
\text { фотохимичес- } \\
\text { кого смога, } \\
\text { кг этилен-экв. }\end{array}$ \\
\hline $\begin{array}{l}\text { Каменная вата, } \\
\text { производство } \\
\text { на территории } \\
\text { Германии }\end{array}$ & 1,37 & $8 \times 10^{-3}$ & $1,3 \times 10^{-7}$ & $8,9 \times 10^{-4}$ & $8,9 \times 10^{-4}$ \\
\hline $\begin{array}{l}\text { Стекловата, } \\
\text { производство на } \\
\text { территории Германии }\end{array}$ & 2,09 & $15,3 \times 10^{-3}$ & $1,1 \times 10^{-7}$ & $9,2 \times 10^{-4}$ & $9,1 \times 10^{-4}$ \\
\hline $\begin{array}{l}\text { Каменная вата, } \\
\text { усредненные } \\
\text { показатели по } \\
\text { производителям на } \\
\text { территории } \\
\text { Европейской части } \\
\text { России }\end{array}$ & 2,21 & $9,8 \times 10^{-3}$ & $1,7 \times 10^{-7}$ & $9,7 \times 10^{-4}$ & $9,3 \times 10^{-4}$ \\
\hline
\end{tabular}

Естественно, рассчитанные эквивалентные показатели первичных энергозатрат, потенциала создания парникового эффекта и потенциала закисления приводятся к соответствующей толщине слоя теплоизоляционного материала, который позволяет достичь определенного сопротивления теплопередаче (при этом площадь поверхности теплоизоляционного материала принимается $1 \mathrm{~m}^{2}$ ).

Постепенно потребители начинают обращать внимание на вопрос экологичности материалов, используемых при строительстве и ремонте. Например, все заводы группы ROCKWOOL стремятся к увеличению объемов вторичной переработки. В настоящее время 80 \% остаточных материалов от производства каменной ваты на предприятиях ГК ROCKWOOL подвергается вторичной переработке. И этот показатель непрерывно растет.

Многие годы ГК ROCKWOOL совершенствует процессы переработки. Отходы производства каменной ваты и остаточные материалы из других отраслей промышленности (имеющие пригодный химический состав) прессуются в брикеты вторичного сырья, которые затем подвергаются 
плавлению и переработке в каменную вату. Это очень важно, поскольку именно в строительной отрасли образуется основная часть материалов, заполняющих свалки.

В отношении этапов монтажа и эксплуатации волокнистых теплоизоляционных изделий следует отметить два важных направления: прямые воздействия на окружающую среду на этих этапах и косвенные воздействия на окружающую среду, связанные с последующей переработкой отработавших изделий.

Первое направление тесно взаимосвязано с эксплуатационными свойствами теплоизоляционных материалов. Например, их водостойкостью, эмиссией волокна и, в конечном итоге, долговечностью. Только долговечный материал может быть положительно оценен с точки зрения безопасности для окружающей среды. В отношении возможных эмиссий волокна существуют различные мнения специалистов, составленные ими по данным собственных исследований. Специалисты НИИ строительной физики РААСН отмечают, что эмиссия волокна из теплоизоляционных изделий не обнаружена за 2 года исследований (скорость воздуха над поверхностью - до 15 м/c), но говорят о необходимости дальнейших исследований [5]. Специалисты из Германии отмечают возможность повышения концентрации волокна (до нескольких тысяч волокон на 1 м $^{3}$ в воздухе помещений) при неграмотном монтаже или повреждении элементов с теплоизоляцией при строительстве [4].

Особенностью эксплуатации, связанной с долговечностью волокнистых материалов, является то, что при длительном воздействии на них повышенных температур (свыше $200{ }^{\circ} \mathrm{C}$ ) может начаться разрушение связующих компонентов. При этом ГОСТ 4640-93 «Вата минеральная. Технические условия», руководствуясь соображениями пожарной безопасности, ограничивает концентрацию вредных веществ (паров углеводородов), выделяющихся из ваты при температуре $40{ }^{\circ} \mathrm{C}$, при насыщенности $0,4 \mathrm{~m}^{2} / \mathrm{M}^{3}$ величиной $1,5 \mathrm{мг} / \mathrm{M}^{3}$. В то же время по стандарту 
DIN 4102-1 минеральные волокнистые изделия относятся к классу пожарной безопасности A1 (без горючих составляющих) и не представляют опасности с точки зрения распространения дыма и огня.

Важнейшим моментом, с точки зрения последующей утилизации волокнистых материалов, является способ их крепления в конструкции. В исследовании теплоизоляционных материалов немецкими специалистами даются экспертные оценки по нагрузкам на окружающую среду (таблица 6) в зависимости от способа крепления [6] оценка дается на качественном уровне без количественных расчетов.

Таблица 6. Масштаб нагрузки на окружающую среду в зависимости от способа крепления теплоизоляции в конструкции

\begin{tabular}{|l|c|c|c|c|}
\hline \multirow{2}{*}{$\begin{array}{c}\text { Вид нагрузки } \\
\text { на } \\
\text { окружающую } \\
\text { среду }\end{array}$} & \multicolumn{2}{|c|}{ Стекловата } & \multicolumn{2}{|c|}{ Каменная вата } \\
\cline { 2 - 5 } & $\begin{array}{c}\text { Свободная } \\
\text { укладка }\end{array}$ & $\begin{array}{c}\text { Местное } \\
\text { закрепление } \\
\text { Энеричнзатраты }\end{array}$ & $\begin{array}{c}\text { Свободная } \\
\text { укладка }\end{array}$ & $\begin{array}{c}\text { Местное } \\
\text { закрепление }\end{array}$ \\
\hline $\begin{array}{l}\text { Парниковый } \\
\text { эффект }\end{array}$ & Средне & Средне & Средне & Средне \\
\hline $\begin{array}{l}\text { Потенциал } \\
\text { закисления }\end{array}$ & Незначительно & Незначительно & Слабо & Слабо \\
\hline $\begin{array}{l}\text { Повторная } \\
\text { переработка } \\
\begin{array}{l}\text { (атраты на } \\
\text { повторное } \\
\text { использование) }\end{array}\end{array}$ & Незначительно & Невозможно & Средне & $\begin{array}{c}\text { Высоко и даже } \\
\text { невозможно }\end{array}$ \\
\hline $\begin{array}{l}\text { Класс } \\
\text { депонирования }\end{array}$ & I & I & I & I \\
\hline
\end{tabular}

Для создания объективной картины необходимо отметить и положительные аспекты воздействия на окружающую среду теплоизоляционных материалов из минеральной ваты. Во-первых, при их производстве потребляется значительно меньше энергоресурсов, чем при выпуске таких строительных материалов, как бетон и кирпич, снижается количество выбросов в атмосферу. Во-вторых, применение теплоизоляционных материалов из минеральной ваты позволяет существенно экономить на отоплении, поскольку такая теплоизоляция 
обеспечивает высокий уровень теплозащиты. А это значит, что и выбросы при производстве отопительной энергии уменьшаются.

Кроме описанных критериев оценки воздействий на окружающую среду группа исследователей из Института прикладных исследований окружающей среды «Катализ» (г. Кельн, Германия) считает важным анализ специальной системы критериев по управлению отходами волокнистых теплоизоляционных материалов, основным из которых является качество использования отходов или их удаления [7]. Одной из сложностей создания такой системы, под эгидой Министерства окружающей среды Федеральной земли Шлезвиг, является частое отсутствие возможности расчета в сравнимых численных величинах. Вследствие чего была разработана оценочная схема, которая позволяет провести анализ возможного повторного использования теплоизоляционных материалов [6]. Причем в дополнение к этим возможностям также учитываются параметры эффективности термической утилизации, компостирования материалов, а также количество вредных веществ, при их депонировании. Эта оценочная схема представлена в таблице 7.

C точки зрения рационального управления отходами, повторное использование предпочтительнее их ликвидации. Среди различных видов повторного использования также следует выбирать наиболее безопасный для окружающей среды способ, обладающий меньшими нагрузками на окружающую среду. При этом следует учитывать, что преимущество повторного использования и утилизации над удалением и ликвидацией отходов может потерять свою пригодность, если ликвидация отходов создает меньшее количество нагрузок на окружающую среду.

Как правило, минеральные материалы в конце своего срока службы депонируются на полигонах. Исходящая от них опасность не так высока по сравнению с другими видами отходов. Захоронение на полигоне проводится по классам отходов 0, I или II в зависимости от того, какие вещества могут выделяться из отходов, а также от количества в материалах органической 
составляющей, которая может создать проблемы для окружающей среды в процессе разложения. В частности, изделиям из стекловаты и каменной ваты присваивается класс I (минеральные отходы) (таблица 7).

Таблица 7. Схема для экологической оценки теплоизоляционных материалов (по Р. Бушману)

\begin{tabular}{|c|c|c|c|c|c|}
\hline \multirow{2}{*}{$\begin{array}{c}\text { Критерии } \\
\text { оценки материалов }\end{array}$} & \multicolumn{5}{|c|}{ Схема оценки } \\
\hline & Очень плохо & Плохо & Средне & Хорошо & $\begin{array}{c}\text { Очень } \\
\text { хорошо }\end{array}$ \\
\hline $\begin{array}{l}\text { Первичные } \\
\text { энергозатраты } \\
\text { Потенциал } \\
\text { создания } \\
\text { парникового } \\
\text { эффекта } \\
\text { Потенциал } \\
\text { окисления }\end{array}$ & $\begin{array}{l}\text { Очень } \\
\text { высоки }\end{array}$ & Высоки & Средние & Низкие & $\begin{array}{l}\text { Очень } \\
\text { низкие }\end{array}$ \\
\hline $\begin{array}{l}\text { Затраты на } \\
\text { повторное } \\
\text { использование и } \\
\text { переработку } \\
\end{array}$ & Невозможно & $\begin{array}{c}\text { Очень } \\
\text { высокие }\end{array}$ & Высокие & Средние & Малые \\
\hline $\begin{array}{l}\text { Термическая } \\
\text { утилизация }\end{array}$ & Невозможно & $\begin{array}{c}\text { Малая } \\
\text { степень }\end{array}$ & $\begin{array}{l}\text { Средняя } \\
\text { степень }\end{array}$ & $\begin{array}{c}\text { Высокая } \\
\text { степень }\end{array}$ & $\begin{array}{c}\text { Очень } \\
\text { высокая } \\
\text { степень }\end{array}$ \\
\hline Компостирование & Невозможно & - & - & - & Возможно \\
\hline $\begin{array}{l}\text { Класс отходов при } \\
\text { депонировании }\end{array}$ & $\begin{array}{c}\text { IV } \\
\text { (Очень } \\
\text { высокий) }\end{array}$ & $\begin{array}{c}\text { III } \\
\text { (Высокий) }\end{array}$ & $\begin{array}{c}\text { II } \\
\text { (Средний) }\end{array}$ & $\begin{array}{c}\text { I } \\
\text { (Низкий) }\end{array}$ & $\begin{array}{c}0 \\
\text { (Очень } \\
\text { низкий) }\end{array}$ \\
\hline
\end{tabular}

Оценка возможности переработки использованных волокнистых теплоизоляционных материалов приведена в таблице 8. В качестве продуктов, получаемых в результате переработки, выступают новые изделия из каменной ваты или стекловаты. При этом некоторые специалисты считают переработку (рециклинг) стекловаты и каменной ваты невозможным [8]. 
Таблица 8. Оценка возможности переработки волокнистых теплоизоляционных материалов

\begin{tabular}{|c|c|c|c|c|}
\hline \multirow{2}{*}{$\begin{array}{c}\text { Наименование } \\
\text { теплоизоляционного } \\
\text { материала }\end{array}$} & \multicolumn{2}{|c|}{$\begin{array}{c}\text { Затраты на переработку } \\
\text { в зависимости от крепления } \\
\text { на объекте }\end{array}$} & \multirow[t]{2}{*}{ Способ } & \multirow[t]{2}{*}{ Продукты } \\
\hline & $\begin{array}{c}\text { Свободная } \\
\text { укладка }\end{array}$ & $\begin{array}{c}\text { Локальное } \\
\text { закрепление }\end{array}$ & & \\
\hline Стекловата & Незначительное & Очень высокие & $\begin{array}{l}\text { Очистка, } \\
\text { включая }\end{array}$ & $\begin{array}{c}\text { Новая } \\
\text { стекловата }\end{array}$ \\
\hline Каменная вата & Средние & Высокие & $\begin{array}{l}\text { пленочных } \\
\text { покрытий, } \\
\text { плавление }\end{array}$ & $\begin{array}{c}\text { Новая каменная } \\
\text { вата }\end{array}$ \\
\hline
\end{tabular}

Термическая обработка, компостирование и захоронение изделий из стекловаты и каменной ваты либо невозможны, либо не применяются. При этом способ переработки изделий предусматривает очистку изделий от покрытий и от связующего. Среди способов освобождения отработанных волокнистых теплоизоляционных материалов от органических компонентов известны термическая и механическая обработки. В таблице 9 приведены некоторые способы переработки отходов теплоизоляционных материалов.

Выбор способа переработки отходов минеральной ваты требует проведения анализа воздействий на окружающую среду по рассмотренным выше критериям, приведенным в стандарте ИСО 14040.

К экономически и экологически эффективным технологическим решениям относится использование в качестве сырья для теплоизоляционных материалов значительного количества отходов [5].

Необходимо проведение более глубоких экспериментов с применением современной аппаратуры [9] непосредственно в местах использования теплоизоляционных материалов на предмет воздействия на экологическую среду. 
Таблица

9. Способы

переработки

отходов

волокнистых теплоизоляционных материалов

\begin{tabular}{|c|c|c|}
\hline $\begin{array}{c}\text { Наименование способа } \\
\text { и разработчик }\end{array}$ & Характеристика способа & Область применения \\
\hline $\begin{array}{l}\text { Метод и устройство } \\
\text { для обработки отходов } \\
\text { минеральной ваты }\end{array}$ & $\begin{array}{l}\text { Измельчение волокон и их } \\
\text { последующая грануляция в } \\
\text { частицы размером до } 50 \text { мм. } \\
\text { Последуюее удаление излишков } \\
\text { влаги и полимеризация } \\
\text { связующего }\end{array}$ & $\begin{array}{l}\text { Использованные } \\
\text { волокнистые } \\
\text { теплоизоляционные изделия }\end{array}$ \\
\hline $\begin{array}{l}\text { Установка } \\
\text { для переработки } \\
\text { отходов производства } \\
\text { минеральной ваты } \\
\text { (Патент РФ 2044711) }\end{array}$ & $\begin{array}{l}\text { Возврат отходов в плавильную } \\
\text { печь после дробильного } \\
\text { устройства в виде дисмембратора. } \\
\text { Механизм возврата отходов в } \\
\text { плавильную печь состоит из } \\
\text { двухрукавной течки, } \\
\text { расположенной под выходным } \\
\text { отверстием дисмембратора, } \\
\text { перекидного шибера и } \\
\text { расположенных у каждой течки } \\
\text { последовательно двухвинтового } \\
\text { конвейера, цепного элеватора, } \\
\text { бункера и шнекового загрузчика }\end{array}$ & $\begin{array}{l}\text { Преимущественно волокна, } \\
\text { не попавшие в изделие в } \\
\text { процессе производства }\end{array}$ \\
\hline
\end{tabular}

\section{Выводы}

В результате проведенного анализа воздействий на окружающую среду по жизненному циклу волокнистых теплоизоляционных материалов установлено, что система рассмотренных критериев по стандарту ИСО 14040 не позволяет подробно учитывать локальные воздействия на экосистемы вблизи производств. Вблизи расположения производства следует учитывать отдельные локальные критерии, позволяющие более объективно оценивать экологическую безопасность предприятийпроизводителей волокнистых теплоизоляционных материалов.

В связи с этим необходимо проведение более глубоких экспериментов с применением современной аппаратуры непосредственно в местах использования теплоизоляционных материалов на предмет воздействия на экологическую среду.

Для этого необходимо проведение многофакторного эксперимента, в качестве входных параметров рекомендуются: X1 - марка 
теплоизоляционного материала (ТИМ); Х2 - размеры ТИМ; Х3 - состав ТИМ; а выходных - У1 - пыль; У2 - содержание химических примесей.

\section{Список используемых источников}

1. «Начинка для бутерброда» - рынок минеральной ваты для изготовления сэндвич-панелей // Index Box. 23.03.2008. URL: https://www.indexbox.ru/research/publications/nachinka-dlja-buterbroda-rynokmineralnoj-vaty-dlja-izgotovlenija-sendvich-panelej/ (дата обращения: 13.12.2020).

2. Буянтуев С.Л., Дамдинова Д.Р., Сультимова В.Д. Технология получения эффективной базальтовой теплоизоляции $\mathrm{c}$ помощью низкотемпературной плазмы // Строительные материалы, оборудование, технологии XXI века. 2006. № 12. С. 70-72.

3. Секисов Г.В., Нигай Е.В., Малыгин В.И., Ищук Н.М. Минеральносырьевая база строительных горных пород центральной зоны Дальневосточного региона // Строительные материалы. 2006. № 8. С. 56-58.

4. AUB-DRW-10305-D. AUB Umweltdeklaration. Unkaschierte bzw. Unbeschichtete Kunstharzgebundene Steinwolle-Dammstoffe. Konigswinter: Arbeitsgemeinschaft Umweltvertragliches Bauprodukt e.V., 2005. 14 p.

5. Газизов А.М. Заиров А.А. Подбор теплоизоляционного материала для пожарного трубопровода // Материалы II Международной научнопрактической конференции. Уфа: Изд-во УГНТУ, 2019. С. 137.

6. Buschmann R. Umweltvertraglichkeit von Gebaudedammstoffen. Kiel: Ministerium fur Umwelt, Natur und Forsten, Schleswig-Holstein, 2018. 81 s.

7. Gutachten Nr. 96-08-33. Arbeitsgemeinschaft Umweltvertragliches Bauprodukt e.V. Munchen: BTU, Buro fur Technischen Umweltschutz, Reiskirchen.

8. Glucklich D. Umweltpass fur Gebaude, Ausgabe 2/97. Hamburg: Technische Universitat Hamburg, 2017. 87 s. 
9. Побединский В.В., Газизов А.М., Санников С.П., Побединский А.А. Диэлектрическая проницаемость лесного фонда в зависимости от параметров среды при радиочастотном мониторинге // Вестник Мордовского университета. 2018. Т. 28. № 2. С. 148-163. DOI: 10.15507/0236-2910.028.201802.148-163.

\section{References}

1. «Nachinka dlya buterbroda» - rynok mineral'noi vaty dlya izgotovleniya sendvich-panelei [«Sandwich Filling» - the Market of Mineral Wool for the Production of Sandwich Panels]. Index Box. 23.03.2008. Available at: https://www.indexbox.ru/research/publications/nachinka-dlja-buterbroda-rynokmineralnoj-vaty-dlja-izgotovlenija-sendvich-panelej/ (accessed 13.12.2020). [in Russian].

2. Buyantuev S.L., Damdinova D.R., Sultimova V.D. Tekhnologiya polucheniya effektivnoi bazal'tovoi teploizolyatsii $\mathrm{s}$ pomoshch'yu nizkotemperaturnoi plazmy [Technology for Obtaining Effective Basalt Thermal Insulation Using Low-Temperature Plasma]. Stroitel'nye materialy, oborudovanie, tekhnologii XXI veka - Building Materials, Equipment, Technologies of the XXI Century, 2006, No. 12, pp. 70-72. [in Russian].

3. Sekisov G.V., Nigai E.V., Malygin V.I., Ishchuk N.M. Mineral'nosyr'evaya baza stroitel'nykh gornykh porod tsentral'noi zony Dal'nevostochnogo regiona [Mineral Resource Base of Building Rocks of the Central Zone of the Far Eastern Region]. Stroitel'nye materialy - Stroitel'nye Materialy (Construction Materials), 2006, No. 8, pp. 56-58. [in Russian].

4. AUB-DRW-10305-D. AUB Umweltdeklaration. Unkaschierte bzw. Unbeschichtete Kunstharzgebundene Steinwolle-Dammstoffe. Konigswinter, Arbeitsgemeinschaft Umweltvertragliches Bauprodukt e.V., 2005. 14 s. [in German]. 
5. Gazizov A.M. Zairov A.A. Podbor teploizolyatsionnogo materiala dlya pozharnogo truboprovoda [Selection of Heat-Insulating Material for a Fire Pipeline]. Materialy II Mezhdunarodnoi nauchno-prakticheskoi konferentsii [Materials of the II International Scientific and Practical Conference]. Ufa, UGNTU Publ., 2019, pp. 137. [in Russian].

6. Buschmann R. Umweltvertraglichkeit von Gebaudedammstoffen. Kiel, Ministerium fur Umwelt, Natur und Forsten, Schleswig-Holstein, 2018. 81 s. [in German].

7. Gutachten Nr. 96-08-33. Arbeitsgemeinschaft Umweltvertragliches Bauprodukt e.V. Munchen, BTU, Buro fur Technischen Umweltschutz, Reiskirchen. [in German].

8. Glucklich D. Umweltpass fur Gebaude, Ausgabe 2/97. Hamburg, Technische Universitat Hamburg, 2017. 87 s. [in German].

9. Pobedinskii V.V., Gazizov A.M., Sannikov S.P., Pobedinskii A.A. Dielektricheskaya pronitsaemost' lesnogo fonda $\mathrm{v}$ zavisimosti ot parametrov sredy pri radiochastotnom monitoringe [Dielectric Permeability of Forestry Depending on Environmental Parameters in Radio Frequency Monitoring]. Vestnik Mordovskogo universiteta - Mordovia University Bulletin, 2018, Vol. 28, No. 2, pp. 148-163. DOI: 10.15507/0236-2910.028.201802.148-163. [in Russian]. 


\section{Сведения об авторах}

\section{About the authors}

Газизов Асгат Мазхатович, д-р техн. наук, профессор, профессор кафедры «Пожарная и промышленная безопасность», УГНТУ, г. Уфа, Российская Федерация; профессор кафедры управления техническими системами и инновационных технологий, Уральский государственный лесотехнический университет, г. Екатеринбург, Российская Федерация

Asgat M. Gazizov, Doctor of Engineering Sciences, Professor, Professor of Fire and Industrial Safety Department, USPTU, Ufa, Russian Federation; Professor of Management of Technical Systems and Innovative Technologies Department, Ural State Forest Engineering University, Ekaterinburg, Russian Federation

e-mail: ashatgaz@mail.ru

Заиров Айдар Алекович, магистрант кафедры «Пожарная и промышленная безопасность», УГНТУ, г. Уфа, Российская Федерация

Aidar A. Zairov, Undergraduate Student of Fire and Industrial Safety Department, USPTU, Ufa, Russian Federation

e-mail: ayydar-z@ rambler.ru

Янгирова Регина Рамилевна, магистрант кафедры «Пожарная и промышленная безопасность», УГНТУ, г. Уфа, Российская Федерация

Regina R. Yangirova, Undergraduate Student of Fire and Industrial Safety Department, USPTU, Ufa, Russian Federation

e-mail: regina-moda@mail.ru

Тимеров Марсель Ринатович, магистрант кафедры «Пожарная и промышленная безопасность», УГНТУ, г. Уфа, Российская Федерация

Marsel R. Timerov, Undergraduate Student of Fire and Industrial Safety Department, USPTU, Ufa, Russian Federation

e-mail: timerov1142@gmail.com 